\title{
Sifat Fisikokimia Dendeng Sapi yang Direndam dalam Gula-Kelapa dan Madu
}

\section{The Physico-Chemical Properties of Indonesian Dried Beef Immersed in Palm Sugar and Honey}

Yessy Tamu Ina ${ }^{1 *}$, Widiyanto ${ }^{2}$, Valentinus Priyo Bintoro ${ }^{3}$

${ }^{1}$ Magister IImu Ternak, Fakultas Peternakan dan Pertanian, Universitas Diponegoro, Semarang

${ }^{2}$ Depertemen Peternakan, Fakultas Peternakan dan Pertanian, Universitas Diponegoro, Semarang

${ }^{3}$ Departemen Pertanian, Fakultas Peternakan dan Pertanian, Universitas Diponegoro, Semarang

*Korespondensi dengan penulis (yessytamuina03@gmail.com)

Artikel ini dikirim pada tanggal 29 November 2018 dan dinyatakan diterima tanggal 27 Januari 2019. Artikel ini juga dipublikasi secara online melalui https://ejournal2.undip.ac.id/index.php/jatp. Hak cipta dilindungi undang-undang. Dilarang diperbanyak untuk tujuan komersial.

Diproduksi oleh Indonesian Food Technologists® @2019

\begin{abstract}
Abstrak
Penelitian ini bertujuan untuk menganalisis sifat fisikokimia pada dendeng sapi setelah dilakukan perendaman dengan gula kelapa dan madu. Penelitian ini terdiri atas 4 perlakuan variasi konsentrasi gula kelapa dan madu, yaitu: 30:0\%, 22,5:7,5\%, 15:15\%, 7,5:22,5\%. Kadar fruktosa, glukosa, kadar air, aktivitas air diamati pada dendeng hasil perlakuan. Data dianalisis dengan ANOVA dan dilanjutkan dengan Uji Jarak Berganda Duncan. Hasil penelitian menunjukkan bahwa peningkatan proporsi madu dalam larutan perendam dapat secara nyata menurunkan kandungan fruktosa, glukosa, kadar air, aktivitas air pada dendeng sapi. Kesimpulannya, sifat fisikokimia dendeng dapat berubah sesuai dengan proporsi konsentrasi gula kelapa dan madu.
\end{abstract}

Kata Kunci: daging, gula kelapa, madu, dendeng, fisikokimia

\section{Abstract}

This study aimed to investigate the physics-chemical aspect of Indonesian dried beef that was immersed in palm sugar and honey. Four ratios of palm sugar and honey were used, i.e. 30:0\%, 22.5:7.5\%, 15:15\%, 7.5:22.5\%. The level of fructose, glucose, water content, and water activity were analysed as the dried beef quality. Data were analyzed using analysis of variance and followed by Duncan's Multiple Range Test. The results indicated that the elevation in the honey concentration in the ratio of immersion provided significant effect on decrease in fructose and glucose levels, water content, water activity. As conclusion, the ratio of palm sugar and honey might provide the effect on the change of fructose and glucose levels, water content, water activity.

\section{Keywords: meat, palm sugar, honey, dried beef, physics-chemical}

\section{Pendahuluan}

Daging merupakan bahan pangan yang bernilai gizi tinggi dan salah satu komoditas sumber protein hewani yang penting untuk kesehatan dan pertumbuhan (Komariah et al., 2009). Kandungan protein $18,4-21,2 \%$, lemak $8,3-12,3 \%$, total abu atau mineral $0,9-1,2 \%$ dan kadar air 66,1-69,3\% pada daging dapat menjadi lingkungan yang ideal bagi pertumbuhan mikroba yang merugikan (Bintoro, 2008) sehingga apabila tidak segera ditangani sejak pemotongan, dapat menurunkan kualitas daging tersebut (Arizona et al., 2011; Kuntoro et al., 2013., Juniawati et al., 2017). Penanganan yang dilakukan diantaranya dengan mengolah daging menjadi dendeng yang berguna untuk mempertahankan kualitas daging (Veerman et al., 2013). Penambahan bahan lain seperti gula kelapa dan madu juga dapat digunakan karena dapat berfungsi untuk mempertahankan kualitas karena dinilai dapat untuk mengatur kadar air, aktifitas air $\left(a_{w}\right)$, dan menambah nilai gizi produk (Purnomo, 1992; Putra et al., 2009; dan Pursudarsono et al., 2015).

Penambahan gula kelapa dalam pembuatan dendeng ternyata dapat meningkatkan kualitas dendeng karena mengandung glukosa yang mencapai $8,96 \%$ serta fruktosa hingga $9,00 \%$, dan juga dapat memberi flavor yang khas serta warna coklat pada dendeng (Purnomo, 1992). Penambahan gula merah ternyata dapat menghasilkan dendeng dengan kadar air yang rendah hingga 5,60\% (Husna et al., 2014). Dalam rangka untuk menghambat pertumbuhan bakteri, maka madu dinilai dapat digunakan dalam proses pembuatan dendeng karena dapat menekan kadar air dan menghambat pertumbuhan bakteri (Putra et al., 2009) oleh karena adanya kandungan senyawa asam-asam organik dan senyawa flavonoid di dalamnya. Madu juga dinilai dapat meningkatkan sifat fungsional dendeng karena memiliki sifat antioksidan yang tinggi (Puspitasari, 2007; Jose et al., 2010). Oleh karena pentingnya keberadaan dua komponen tersebut, maka dalam upaya meningkatkan kualitas dendeng, penelitian ini bertujuan untuk menggunakan gula kelapa dan madu pada proses pembuatan dendeng guna meningkatkan kualitas fisik dan kimiawinya. Informasi ini sangat bermanfaat bagi industri pembuatan dendeng agar dapat memberikan alternatif cara meningkatkan kualitas dendeng.

\section{Materi dan Metode \\ Materi}

Bahan yang digunakan dalam penelitian ini adalah daging segar sapi peranakan Ongole bagian bottom round yang diperoleh dari rumah potong hewan (RPH) Penggaron Kota Semarang. Madu diperoleh dari Pulau Timor, Provinsi Nusa Tenggara Timur, gula 
kelapa diperoleh dari Pasar Jati Kota Semarang. Alat yang digunakan dalam penelitian adalah timbangan digital, mesin pengiris daging, pisau stainless steel, beaker glass, High Perfomance Liquid Chromatography (HPLC) (Knauer Smartline 1000, Jerman), aw meter (Novasina, Switzerland), dan oven.

\section{Metode Penelitian}

Penelitian ini dilaksanakan selama tiga bulan yaitu pada bulan Juni sampai dengan Agustus 2018 di Laboratorium Terpadu Universitas Diponegoro dan Laboratorium Penelitian dan Pengujian Terpadu Universitas Gadjah Mada, Yogyakarta. Penelitian ini menggunakan Rancangan Acak Lengkap dengan 4 perlakuan kombinasi perendaman daging dalam larutan gula kelapa dan madu dengan konsentrasi yang bervariasi, yaitu $T_{0}$ adalah kontrol dengan gula kelapa $30 \%+$ madu $0 \% ; \mathrm{T}_{1}$ adalah gula kelapa $22,5 \%+$ madu $7,5 \% ; \mathrm{T}_{2}$ adalah gula kelapa $15 \%+\operatorname{madu} 15 \%$; dan $\mathrm{T}_{3}$ adalah gula kelapa $7,5 \%+$ madu $22,5 \%$. Masingmasing perlakuan diulang sebanyak 5 kali. Variabel yang diukur adalah kadar fruktosa, glukosa, kadar air dan aktivitas air $\left(\mathrm{a}_{\mathrm{w}}\right)$.

\section{Prosedur Pengolahan Dendeng}

Pembuatan dendeng didahului dengan menghilangkan lemak eksternal pada daging dan tahap selanjutnya daging diiris secara melintang dengan ketebalan $3 \mathrm{~mm}$ (Handayani et al., 2015). Potongan daging selanjutnya dibagi sesuai ulangan perlakuan perendaman. Kegiatan selanjutnya adalah pengeringan pada suhu $55^{\circ} \mathrm{C}$ dan dengan lama waktu masingmasing 4 jam. Daging yang sudah kering, diuji kadar fruktosa, kadar glukosa, kadar air, dan aktivitas air $\left(\mathrm{a}_{\mathrm{w}}\right)$.

\section{Uji Gula Fruktosa dan Glukosa}

Metode pengujian gula dilakukan dengan HPLC yang dibantu dengan detektor refraktor indeks dan dengan fase gerak berupa $\mathrm{H}_{2} \mathrm{O}$ dengan waktu alir 0,5 $\mathrm{mm} /$ menit. Kolom yang digunakan adalah Aminex HPX$87 \mathrm{H} 300 \times 7,8 \mathrm{~mm}$ dengan suhu kolom $45^{\circ} \mathrm{C}$ sesuai dengan peneliti sebelumnya (Al-Baarri, 2003). Preparasi sampel dilakukan dengan menggunakan $2 \mathrm{~g}$ sampel yang dilarutkan dalam TCA yang selanjutnya mengikuti prosedur sebagaimana telah dijelaskan pada peneliti sebelumnya (AI-Baarri, 2003)

\section{Kadar Air dan Aktivitas Air}

Analisis kadar air menggunakan metode oven (AOAC 1995). Pengukuran nilai aktivitas air diukur menggunakan $a_{w}$ meter. Alat dikalibrasikan terlebih dahulu dengan larutan $\mathrm{NaCl}$ jenuh. Pengukuran dilakukan pada sampel sebanyak $5 \mathrm{~g}$ dendeng yang sudah dihaluskan (Syarief et al., 1993).

\section{Uji Statistik}

Data yang diperoleh meliputi kadar air dan aktivitas air diuji normalitasnya dengan menggunakan uji Shapiro-Wilk. Apabila sebaran datanya normal dianalisis dengan ANOVA pada taraf $5 \%$. Pada taraf $5 \%$ dilanjutkan dengan uji Wilayah Ganda Duncan
(Steel et al., 1997). Data fruktosa dan glukosa di uji secara deskriptif.

\section{Hasil dan Pembahasan}

Kadar Fruktosa

Hasil penelitian (Tabel 1) menunjukkan tidak terdeteksinya kadar fruktosa pada sampel tanpa penambahan madu $\left(\mathrm{T}_{0}\right)$, hal ini diasumsikan bahwa gula kelapa tidak mengandung fruktosa sehingga menyebabkan tidak terdeteksinya fruktosa pada dendeng yang dihasilkan. Dendeng sapi dengan kombinasi gula kelapa dan madu pada perlakuan $\mathrm{T}_{2}$ memiliki kadar fruktosa dan glukosa tertinggi, yaitu masing-masing 27,734 dan $11,48 \%$. Tingginya kadar fruktosa dan glukosa dendeng sapi diduga oleh karena tingginya kadar air. Perhitungan standardisasi kadar air menjadi $20 \%$, tetap menunjukkan bahwa kandungan fruktosa dan glukosa pada $T_{2}$ nampak tertinggi (Tabel 2).

Beberapa peneliti terdahulu menyatakan bahwa perbandingan antara fruktosa dan glukosa yang digunakan sebagai pemanis oleh industri makanan adalah 55 dan 45\% (Basciano et al., 2005; Bantle et al., 2009; dan Johnson et al., 2009) yang menunjukkan proporsi fruktosa yang lebih besar daripada glukosa, dan linear dengan hasil penelitian ini menunjukkan proporsi fruktosa yang lebih besar dibandingkan dengan glukosa dengan proporsi masing-masing sebesar 23,818 dan $6,83 \%$ (pada $T_{1}$ ) dan 25,627 dan $6,16 \%$ (pada $T_{3}$ ). Namun demikian proporsi fruktosa yang terlampau besar, tidak dapat terabsorpsi di dalam tubuh (Stanhope et al., 2009).

Tabel 1. Kadar Fruktosa dan Glukosa (\%)Dendeng Sapi dengan Kombinasi Gula Kelapa dan Madu

\begin{tabular}{lcc}
\hline Perlakuan & Fruktosa & Glukosa \\
\hline T0 & TT & 6,19 \\
T1 & 23,818 & 6,83 \\
T2 & 27,734 & 11,48 \\
T3 & 25,627 & 6,16 \\
\hline
\end{tabular}

Tabel 2. Kadar air (\%), aktivitas air, fruktosa (\%) glukosa (\%) pada dendeng sapi dengan perlakuan perendaman dalam gula kelapa dan madu

\begin{tabular}{lcccc}
\hline Perlakuan & Kadar air & Aktivitas air & Fruktosa $^{*}$ & Glukosa $^{*}$ \\
\hline T0 & $34,09 \pm 3,12^{\mathrm{a}}$ & $0,75 \pm 0,01^{\mathrm{a}}$ & TT & 10,55 \\
T1 & $33,10 \pm 2,52^{\mathrm{a}}$ & $0,73 \pm 0,02^{\mathrm{a}}$ & 39,41 & 11,30 \\
T2 & $31,85 \pm 1,13^{\mathrm{a}}$ & $0,72 \pm 0,02^{\mathrm{a}}$ & 44,16 & 18,28 \\
T3 & $25,26 \pm 2,33^{\mathrm{b}}$ & $0,66 \pm 0,03^{\mathrm{b}}$ & 32,36 & 7,78
\end{tabular}

Keterangan untuk Tabel 1 dan Tabel 2: Superskrip ab yang berbeda pada kolom yang sama menunjukkan perbedaan nyata $(P<0,05)$. Tanda * artinya nilai setelah standarisasi berdasarkan $20 \%$ kadar air. $\mathrm{T}_{0}, \mathrm{~T}_{1}, \mathrm{~T}_{2}, \mathrm{~T}_{3}$ adalah perendaman daging dengan gula kelapa dan madu masing-masing dengan perbandingan 30:0, 22,5:7,5; 15:15, 7,5:22,5\%. TT artinya tidak terdeteksi.

\section{Kadar Glukosa}

Berdasarkan hasil penelitian yang tertera pada Tabel 1, kadar glukosa pada dendeng $\mathrm{T}_{0}$ sebesar $6,19 \%$ yang diduga merupakan kandungan glukosa yang berasal dari gula kelapa. Kadar glukosa tersebut kemudian meningkat pada $T_{1}$ dan $T_{2}$ namun kemudian menurun di $\mathrm{T}_{3}$ yang dimungkinkan karena rendahnya 
kadar air pada $\mathrm{T}_{3}$. Kusnandar (2010) menyatakan bahwa sifat higroskopis gula sederhana adalah disebabkan oleh adanya gugus polihidroksi yang mampu membentuk ikatan hidrogen dengan air. Perhitungan standardisasi kadar air menjadi 20\%, juga menunjukkan bahwa kandungan glukosa pada $\mathrm{T}_{2}$ juga tampak yang tertinggi (Tabel 2). Namun demikian, kandungan fruktosa dan glukosa ini masih berada pada kisaran yang tidak jauh dari hasil penelitian sebelumnya (Purnomo 1992) yang menyatakan bahwa gula kelapa dapat meningkatkan kadar fruktosa dan glukosa pada dendeng yang masing-masing berkisar 2,95-9,00\% dan $3,00-8,96 \%$.

\section{Kadar air}

Pengaruh kombinasi gula kelapa dan madu dengan perbandingan yang berbeda terhadap kadar air dan $a_{w}$ dapat dilihat pada Tabel 2. Hasil analisis ragam menunjukkan, bahwa kombinasi perlakuan konsentrasi gula kelapa dan madu berpengaruh nyata $(P<0,05)$ terhadap kadar air dan $a_{w}$ dendeng sapi. Rata-rata kadar air tertinggi 34,09\% didapat dari perlakuan $\mathrm{T}_{0}$ dan yang terendah, yaitu $25,26 \%$, yang didapat dari perlakuan $\mathrm{T}_{3}$. Proporsi madu yang semakin tinggi dapat menurunkan kadar air (Putra et al., 2009; Syarief dan Halid, 1993; Frandson, 1992).

Berdasarkan pada upaya pencegahan pertumbuhan bakteri, khamir dan kapang, maka perlakuan $T_{3}$ merupakan perlakuan yang terbaik karena mengandung kadar air yang terendah dan mendekati kadar yang ditentukan oleh Direktorat Gizi Depertemen kesehatan RI (1981), yaitu sebesar 25\%. Hal ini dikarenakan konsentrasi gula yang tinggi dan kadar air yang rendah menyebabkan mikroorganisme tidak dapat tumbuh (Voidarou et al., 2011; Kwakman et al., 2012).

\section{Aktivitas air $\left(\mathrm{a}_{\mathrm{w}}\right)$}

Hasil analisis ragam menunjukkan bahwa kombinasi perlakuan konsentrasi gula kelapa dan madu berpengaruh nyata $(P<0,05)$ terhadap $a_{w}$ dendeng sapi. Nilai $a_{w}$ tertinggi dan terendah masing-masing sebesar $0,75 \pm 0,01$ dan $0,66 \pm 0,03$ didapat dari perlakuan $T_{0}$ dan $\mathrm{T}_{3}$. Proporsi madu yang semakin tinggi menghasilkan aktivitas air yang semakin rendah. Hal ini diasumsikan karena efek osmotik yang dihasilkan dari madu (Puspitasari, 2007). Osmosis adalah perpindahan zat atau senyawa kimia dari konsentrasi rendah ke konsentrasi yang lebih tinggi yang dapat membuat kadar air dan aktivitas air di dalam daging menjadi berkurang (Huda, 2013). Hasil penelitian pada perlakuan $T_{3}$ sebagaimana tampil pada Tabel 2, menghasilkan nilai $a_{w}$ sebesar $0,66 \pm 0,03$ yang mendekati penelitian Parsudarsono et al. (2015). Sementara itu, Mandal et al. (2010) dan Moussa et al. (2012) menyatakan bahwa madu menunjukkan aktivitas antibakteri yang sangat baik untuk Esherichia coli, Pseudomonas aeruginosa, Salmonella, dan Streptococus. Selanjutnya Ratna et al. (2017) menyatakan bahwa Campylodabacter Spp mulai tumbuh pada $\mathrm{a}_{\mathrm{w}}=0,98 ; E$. Coli pada 0,95 , Vibrio arahaemolyticus pada 0,94, Salmonella Sp.pada 0,93,
Bacillus cereus pada 0,92, Listeria monocytogenes pada 0,90 dan Staphylococcus aureus pada 0,86. Maka berdasarkan kebutuhan $a_{w}$ minimal tersebut, dendeng sapi semua kombinasi gula kelapa dan madu dapat dikatakan aman untuk mencegah pertumbuhan bakteri, khamir dan kapang.

\section{Kesimpulan}

Proporsi gula kelapa yang semakin menurun dan madu yang semakin meningkat pada proses pembuatan dendeng sapi dapat menurunkan kadar fruktosa, kadar glukosa, kadar air dan $\mathrm{a}_{\mathrm{w}}$.

\section{Daftar Pustaka}

Al-Baarri, A.N. 2003. Analisis perbedaan kolom pada deteksi karbohidrat susu fermentasi dengan metode HPLC. Journal of Indonesian Tropical Animal Agriculture 28 (1): 27-32.

Arizona R., Suryanto, E., Erwanto, Y. 2011. Pengaruh konsentrasi asap cair tempurung kenari dan lama penyimpanan terhadap kualitas kimia dan fisik daging. Jurnal Buletin Peternakan 35(1):5056. DOI.10.21059/buletinpeternak.v35i1.590.

Association of Official Analytical Chemist (AOAC). 1995. Official Methods of Analysis $16 \mathrm{t}^{\mathrm{h}}$ Edition. Maryland (US).

Bantle, J.P. 2009. Dietary fructose and metabolic syndrome and diabetes. The Journal of Nutrition 139(6):1263S-1268S. DOI:10.3945/jn.108. 098020.

Basciano H., Federico, L., Adeli, K. 2005. Fructose, insulin resistance, and metabolic dyslipidemia. Journal of Nutrition and Metabolism 2(5):1-14. DOI:10.1186/1743-7075-2-5.

Bintoro, V.P. 2008. Teknologi Pengolahan Daging dan Analisis Produk. Badan Penerbit Universitas Diponegoro, Semarang.

Direktorat Gizi Departemen Kesehatan RI. 1981. Daftar Komposisi Bahan Makanan. Bhatara Karya Aksara, Jakarta.

Frandson, R.D. 1992. Anatomi dan Fisiologi Ternak Edisi ke-4. Gadjah Mada University Press. Yogyakarta.

Handayani, B.R., Margana, C.C.E., Kartanegara, Hidayati, A., Werdiningsih, W. 2015. Kajian waktu perendaman "marination" terhadap mutu dendeng sapi tradisional siap makan. Jurnal Teknologi dan Industri Pangan 26(1):17-25. DOI:10.6066/jtip.2015.26.1.17.

Huda, M. 2013. Pengaruh madu terhadap pertumbuhan bakteri gram positif (Staphylococus aureus) dan bakteri gram negatif (Eshericia coli). Jurnal Analisis Kesehatan 2(2):250-259. DOI.10.26630/ jak.v212.437.

Husna, N.E., Asmawati, Suwarjana, G., 2014. Dendeng ikan leubiem (Canthidermis maculatus) dengan variasi metode pembuatan, jenis gula, dan metode pengeringan. Jurnal Teknologi dan Industri Pertanian Indonesia 06(03). DOI:10.17969/jtipi.v613.2316. 
Juniawati., Miskiyah., Widaningrum. 2017. Aplikasi vinegar sebagai biopreservative untuk menghambat pertumbuhan salmonella typhimurium pada daging ayam segar. Jurnal Buletin Peternakan 41(2):187-196. DOI.1021059/buletinpeternak.V41i2.13596.

Johnson, R.J., Perez-Posa, S.E., Sautin, Y.Y., Manitius, J., Lozada, I.G., Feig, I. 2009. Hypothesis: could excessive fructose intake and uric acid cause type 2 diabetes? Endocrine Reviews 30(1):96116. DOI:10.121/er.2008-0033.

Jose, M., Suares, A., Tulipani, S., Diaz, D., Estevez,Y., Romandini,S., Giamperi,F., Damiani, E., Astolfi, P., Bompadre, S., Battino, M. 2010. Antioxidant and antimicrobial capacity of several monofloral Cuban honeys and their correlation with color, polyphenol content and other chemical compounds. Food and Chemical Toxicology 48(8-9):2490-2499. DOI:10.1016/j.fct.2010. 06.021.

Kwakman,P.H.S., Zaat, S.A.J., 2012. Antibacterial components of honey. International Union of Biochemistry and Molecular Biology 64(1):48-55. DOI:10.1002/iub.578.

Kusnandar, F . 2010. Kimia Pangan Komponen Makro. Dian Rakyat. Jakarta.

Kuntoro, B., Maheswari, R.R.A., Nuraini, H. 2013. Mutu fisik dan mikrobiologi daging sapi asal rumah potong hewan $(\mathrm{RPH})$ kota Pekanbaru. Jurnal Peternakan 10(1):1- 8. DOI:10.24014/jupet. v10il.152

Komariah., Rahayu, S., Sartijo. 2009. Sifat fisik daging sapi, kerbau dan domba pada lama postmortem yang berbeda. Buletin Peternakan 33(3): 183189. DOI:10.21059/buletinpeternak.v33i3.115.

Mandal, S., DebManda, M., Pal, N.K., Saha K. 2010. Antibacterial activity of honey against clinical isolates of Asherichia coli, Pseudomonas auruginosa and Salmonella enterica serovar Typhi. Asian Pacific Journal of Tropical Medicine 3(12):961-964. DOI:10.1016/S1995-7645(11) 60009-6.

Moussa, A., Noureddine, D., Hammoudi, S.M., Abdelmelek, M., Saad, A. 2012. Antibacterial activity of various honey types of algeria against Staphylococcus aureus and Streptococcus pyogenes. Asian Pacific Journal of Tropikal
Medicine 5(10):773-776. DOI:10.1016/S19957645(12)60141-2.

Purnomo, H., 1992. Volatil Components of Coconut Fresh Sap, Sap Syrup, and Coconut Sugar 14 (1): 45-49 (2007).

Putra, I.S., Mirdhayati, D.I. 2009. Penggunaan madu lebah (Genus Apis) sebagai bahan pengawet alami daging sapi. Jurnal Peternakan 6(1):14-20. DOI:10.24014/jupet.vgil.343

Pursudarsono, Fadimas, Rosyidi D., Widati A. 2015. Pengaruh perlakuan imbangan garam dan gula terhadap kualitas dendeng paru-paru sapi. Jurnal IImu dan Teknologi Hasil Ternak 10(1):35-45. DOI:10.2177/ub.jitek.2015.010.01.5

Puspitasari, I. 2007. Rahasia Sehat Madu. Jogjakarta: B-First ( PT. Bentang Pustaka ).

Ratna, S.S., Agustini, S., Wijaya, A., Pambayun, R. 2017. Profil mutu ikan lele (Clarias gariepinus) asap yang diberi perlakuan gambir (Uncaria gambir Roxb). Jurnal Dinamika Penelitian Industri 28(2):101-111. DOI: 10.28959/jdpi.v28i2.3019.

Stanhope, K.L., Schwarz, J.M., Keim, N.L., Griffen, S.C., Bremer, A.A., Graham, J.L. 2009. Consuming fructose-sweetened, not glucosesweetened, beverages increases visceral adiposity and lipids and decreases insulin sensitivity in overweight/obese humans. The Journal Clinical Investigation 119(5):1322-34. DOI: $10.1172 / \mathrm{JCI} 37385$.

Steel, R.G.D., Torrie, J.H., Dickey, D.A. 1997. Principles and procedures of statistik a biomedical approach, 3rd Edition. McGraw Hill, Inc, Singapore

Syarief, R. Dan Halid, H. 1993. Teknologi Penyimpanan Pangan. Arcan. Jakarta.

Veerman, M., Setiyono., Rusman. 2013. Pengaruh metode pengeringan dan konsentrasi bumbu serta lama perendaman dalam larutan bumbu terhadap kualitas fisik dan sensori dendeng babi. Buletin Peternakan 37(1):34-40. DOI: 10.21059/buletinpeternak.v37il.1957

Voidarou, C., Alexopoulus, A., Plessas, S., Karapanou, A., Mantzourani, I., Stavropoulou, E., Fotou, K., Tzora, A., Skoufos, I., Bezirtzoglou, E. 2011. Antibacterial activity of diffent honeys against pathogenic bacteria. Journal Anaerobe 17(6):375-379. DOI: 10,1016/j.anaerobe. 2011.03 .012 